\title{
The relationship between ineffective methods of applying quality management and functional combustion in Arab Universities
}

\author{
Hoda Ahmed Ibraheem Abdelnabi \\ Faten Ahmed Abobaker \\ Arab East Collages, Kingdom of Saudi Arabia \\ Khaled Mohamed ELBadawey \\ Taif University, Kingdom of Saudi Arabia
}

\begin{abstract}
Keywords
Quality management, functional combustion, Saudi universities, Higher education institutions
\end{abstract}

\begin{abstract}
The study aimed to shed light on the relationship between the ineffective use of quality and functional combustion in Saudi universities. The study used the descriptive-analytical methods, the researchers used the SPSS program for analysis. Higher education institutions seek to apply quality standards to achieve excellence in education and research services and community service, in order to obtain academic accreditation Universities are quick to meet the requirements of accreditation, to achieve these goals, the biggest burden falls on the faculty members "update programs, courses, academic guidance, Also conduct scientific research, attend conferences and provide community service in many forms such as workshops, training programs, consultations " these requirements are the core of the accreditation process and are also closely related to the work of the faculty member, However, the lack of good organization and overload of burden leads to underperformance and outstanding achievement in any of the scientific or research fields. This leads us to enter the stage of " functional combustion, "a state of intellectual, emotional, and physical exhaustion as a result of overwork. So, the problem of the study appears in the main question what is the relationship between the ineffective methods of quality management, functional combustion in the Arab universities?

The results of the study showed there are very negative aspects of the ineffective application of quality at the university, which is reflected by everyone who works in the university field at the level of Arab universities, so led to reducing the important scientific role of the faculty member to become a primary preparatory of quality reports which take all time.

The researchers' recommendations university must study the phenomenon of job combustion and to work out their causes and devise appropriate solutions to mitigate its spread.
\end{abstract}

\section{Introduction}

Higher education institutions strive for the proper and comprehensive application of the concept of total quality management to improve quality levels and enable the organization to excellence. Engaging in the work and ensuring that it is done to the fullest is a positive thing that helps us speed up our practical ambitions, but overemphasis on the tasks of work and the saturation of its problems and pressures may lead us to enter the stage of "functional combustion," a state of intellectual, emotional and physical exhaustion as a result of overwork.

However, the application of quality in a manner that leads to a set of challenges facing the educational institutions, such as waste of human resources and misdirection leads to what is known as institutional burnout, and to meet these challenges had to be the proper and comprehensive application of the concept of total quality management to improve quality levels and enable the organization to excellence. Achieving the quality of education is achieved through the existence of a mechanism that clarifies the policy that the institution should follow from the efficiency of administrative organization and the provision of high-level training systems for the educational and administrative staff. The quality of education is the totality of the attributes and characteristics that relate to the educational service and can meet the needs of students. Educational product. 


\section{The Study Problem}

Higher education institutions face a wave of challenges, such as low productivity, and ineffective methods of achieving quality goals, causing what is known as functional combustion. Hence, we can put the main question of the study:

What is the relationship between ineffective methods of applying quality management and functional combustion in Saudi universities?

\section{Objective Study}

Identify the principles and requirements for applying quality in education, the concept of functional combustion, the cause of functional combustion Requirements for the application of total quality management in higher education, Manifestations of functional combustion, Stages of functional combustion, Dimensions of functional combustion, Treatment and prevention of functional combustion.

\section{The Theoretical Study \\ Theoretical Framework \\ Principles of Quality in Education}

There are a set of principles of quality in education the most important of these principles:

$\square$ Full support from leaders of educational institutions and mechanisms of total quality

$\checkmark$ Change in management style from bullying to the delegation

$\checkmark$ Comprehensive quality as it encompasses all areas of service.

$\square$ Integration of policies to achieve quality and excellence in the chain of quality processes.

Focus on team spirit through the use of flat-panel organizational structures

$\checkmark$ Good use of effective time management and positive coping mechanisms

Providing workers with the culture and skills of "Assertiveness behaviour" in the sense of earning and helping others gain.

$\square$ Develop and activate a system of incentives that takes into account the requirements of regulatory justice.

\section{Requirements for the application of total quality management in higher education}

The application of total quality management in any organization requires the availability of basic skills in the director of total quality and his staff such as: -

- Setting measurable goals and attention to strategic planning.

- Strengthen collective work as the foundations within the organizations.

- Attention to appreciation and rewards when the completion of workers effectively.

- Setting standards for control and the need to use quality tools and processes and rely on the Deming cycle to improve performance.

- Urging individuals to learn from mistakes.

- The ability to provide human relations between employees.

\section{Functional combustion}

Functional burn-out as a disease was approved in the new version (ICD11) by the World Health Organization. when it provides 3 symptoms: - A feeling of energy shortage and fatigue. Increased mental gap from the job and decrease effectiveness.

The definition of "burnout" has been revised by various psychological schools. (Herbert Freudenberger) described burnout terminology as subjective sensation of energy depletion and being overwhelmed with numerous issues concurrently with self-dedication and commitment in work and prove oneself (Doaa, 2019).

burnout is typically described as a reaction to long-lasting untreated occupational stress, which is characterized by three symptoms: exhaustion, cynicism and reduced professional efficacy (Stela, 2017).

Marwan (2016), psychological combustion is a group of symptoms that are nervous strain, exhaustion of emotional energy, impersonation in personal terms, and a feeling of dissatisfaction with achievement in the professional field, which can occur in people who perform a type of work that requires direct dealing with People. 
Shukla \& Trivedi (2008), The inability to fulfil the required service requirements as expected, which is emotional exhaustion, apathy, physical fatigue, low energy, mental illness, increased drug use, and anger is not Justification, frustration, and low personal achievement.

\section{Manifestations of functional combustion.}

Reduced satisfaction rate.

Weak sense of belonging and loyalty to the institution.

Difficulties in work and personal relationships.

Continue working at home.

Neglecting oneself and not being able to control interactions

Health problems, depression - weight gain - pressure diseases.

The imbalance between work and personal life.

Severity of character, behavior change and unwillingness to deal with others, Permanent preoccupation, and rush to finish the long list of actions, and focus on speed, not mastery.

Loss of vision, development, improvement and focus on recurring assignments.

Postponing matters and social activities.

Organic disorders, which may appear in the form of imbalances such as: frustration, anxiety, depression, and speed.

Stages of functional combustion.

Health problems

Realization difficulties

Difficulties in work and personal relationships

Continue working at home

Fatigue

Negativity

Reduced satisfaction rate

Loss of motivation to continue production

Performance issues

Neglecting oneself

Dimensions of functional combustion:

Categorized the dimensions of psychological combustion into three main dimensions, and called it the psychological combustion syndrome (Maslach, 1982), namely:

\section{1- Emotional stress: Emotional Exhaustion}

Emotional stress is the first component of psychological penetration, which can be described as a loss of energy, a state of complete weakness and fatigue, depletion of the individual's emotional and physical resources, a feeling of fatigue and physical exhaustion when making the least effort, as well as a feeling of frustration and irritability, and the inability to make any decision

\section{2- Sagging Depersonalization Sense:}

It is the most extensive dimension, and it indicates a negative shift in reaction to others, as it implies negative attitudes, And inappropriate, and the unity of printing, and the tendency to cruelty, and the loss of human feeling when dealing with others, and individuals experience a feeling that they are no longer able to perform their high levels of naturally.

\section{3- Reduce Feeling of Personal Accomplishment:}

It expresses the self-evaluation of combustion, and it represents a feeling of professional inefficiency or a lack of sense of the efficacy of effort, loss of motivation to accomplish, and the individual tends to assess personality achievement in a negative way, a sense of failure, and poor self-esteem.

\section{Treatment and prevention of functional combustion}

Hogarth, (2017) suggested a number of recommendations to avoid reaching this critical stage, work and its problems should be separated at specific times per day to contribute to driving motivation to work.

Experts also recommend paying attention to any new physical or psychological symptoms, such as permanent headaches also possible to resist "functional combustion" through measures such as setting 
times for relaxation and engaging in loved activities, giving up sleeping pills, organizing time to make the most of it without suffering from stress, taking time to rest on the working day, even for a few minutes, and stay away from people Negative or frustrated.

\section{Literature review}

Doaa, (2019), functional combustion and Job Satisfaction among Healthcare Providers in Aswan University Hospital, Upper Egypt 'Background \& Objective (s): The study aimed to assess the levels of burnout and job satisfaction as well as their correlates among healthcare providers in Aswan University Hospital. Methods: A cross sectional study design was applied. Interviewing questionnaire was filled from 134 physicians and 149 nurses (total 283) working in clinical departments in Aswan University Hospital.

Results: Proportion of high level in burnout dimensions were as follows: emotional exhaustion was $50 \%$, low personal accomplishment was 39\% and depersonalization was 33\%. The mean job satisfaction score among the studied population was 63 . out of 100 . Increasing age was a significant predictor for emotional exhaustion. Currently unmarried significantly perceived higher emotional exhaustion and depersonalization. Higher job satisfaction scores significantly predicted low perception of emotional exhaustion and depersonalization and high personal accomplishment. The significant predictors for job satisfaction were current unmarried status, working as nurse, residing outside Aswan, age increase, high personal accomplishment score and low emotional exhaustion score

The American Psychological Association and the Center for National Opinion Research at the University of Chicago, (2019) found that $48 \%$ of American have experienced an increase in stress levels over the past 5 years. More than half of the respondents $(53 \%)$ said that the work causes them great fatigue.

The American Human Resources Management Association (HRA, 2019), found that "burnout and burnout" is one of the most important reasons for the resignation of many employees., And neglects his personal life.

Nivethitha Santhanam, (2019), Modeling the impact of employee engagement and happiness on burnout and turnover intention among blue-collar workers at a manufacturing company. The purpose of this paper is to examine the impact of engagement on job burnout and turnover intention among bluecollar workers in manufacturing facilities. In addition, this study also explores the role of happiness as a moderator in explaining the effect of engagement on burnout and turnover intention, the results showed the importance of engagement and happiness on reducing burnout and turnover intention. Organizations could capitalize on these findings by implementing new and improving their existing quality management initiatives, which, in turn, could improve the employee's organizational commitment.

Rafsh \& Alrabeay, (2018), the impact of job satisfaction on the success of organizations, this study examined the impact of job satisfaction in organizational success. The study was conducted on a random sample of (87) employees, distributed in several administrative levels. It used a questionnaire as a key tool to collect data and information, as well as personal interviews and observation. The study sought to test a number of hypotheses concerning the main and sub-effect relationships between the variables of the study, based on the study results, it has developed a set of recommendations. It was most important that administration of offices identify employees with dimensions and the importance of job satisfaction and the senior management in the Commission of Integrity must pay attention to organize training courses for leaders and managers, in order to familiarize them with the importance of job satisfaction, and administrative modern approaches that contribute to achieve and increase it.

Akdy, (2017), Organizational Climate and its Relationship with Job Burnout Among Secondary Schools' Teachers in Jazan Region This study aimed to achieve a number of objectives such as: identifying the degree of organizational climate in the public secondary schools in Jazan region, recognizing the level of job burnout among teachers in secondary schools in Jazan, revealing the relationship between organizational climate and job burnout among secondary schools' teachers in Jazan, recognizing differences in study sample responses concerning organizational climate according to (school type, qualification, marital status, experience), and recognizing the differences in rate of burnout among teachers according to (school type, qualification, marital status, experience). , the study shows statistically significant differences between study sample responses concerning organizational climate and the 
following independent variables: school type, experience, and qualification. Statistically, significant differences are also established between the rate of job burnout among teachers and the following independent variables: school type, qualification, and experience. The study suggests a modified model for measuring organizational climate and its relationship with job burnout at public schools. The study also presents a number of recommendations and suggestions which aim to reinforce positive aspects and overcome negative ones in school's organizational climate in order to reduce the level of job burnout among.

\section{Shalan, (2017), Confronting the Job Burnout: Towards a Suggestive Model}

The study seeks to identify the Burnout as a psychological and managerial phenomenon, also the study seeks to address the following main question: Is confronting Burnout the responsibility of individual or leadership? the study yields the following findings: -reasons for Burnout are related - the institutional circumstances; the treatment of the employees; the work pressure; the absence of a role; nonparticipation in decision-making; and the lack of job rotation; the responsibility for Burnout is not confined to any institution, but it extends the leadership responsibility, individual responsibility, and the shared responsibility between the individual and leadership; a model is designed by the researcher to determine the relative responsibility assumed by leadership, individual and shared between them with regard to the prevention and treatment of Burnout.

Mahdi, (2017), The research aimed to investigate the impact of employee's empowerment on job burnout. To achieve this research was conducted on a random sample of (151) employees in the general company of Iraqi ports in Basra. The statistical package for social sciences. The researcher used many statistical methods to achieve the research objectives, such as simple, multi regression and the research results showed there is significant impact to employees' empowerment dimensions on job burnout in the company of the research sample.

Hogarth, M. (2017), "Avoiding Burnout" In terms of the Time Pressure measures (Table1), the local library feels much higher time pressure, and feels slightly busier and in a hurry survey results found that high time pressure and high levels of burnout likely affect patient safety interactions. The researchers recommend: dealing with emotional problems calmly. Enough job resources in terms of physical, emotional, and intellectual support should also be addressed in order to maximize success and avoid burnout, also A fair scale of justice extended across all parts and processes of a library is key to reducing long-term stress. Fairness has a strong positive influence on organizational image, efficiency, and effectiveness. Fairness can be achieved by creating a library climate where workers can freely express themselves and where they can take part in social activities, Opportunities for bonding and socializing allow staff to feel more connected in the library. Partnering across departments for projects, with regular face to- face meetings that emphasize de-briefing, what worked, and what didn't work, allows freer and better communication, growing connectedness.

1Naser, (2017), aims to know the importance of the application of a total quality management system to limit the phenomenon of Job Burnout. The search has taken place in some service government departments in the province of Wasit, and it relied on a scientific peer-reviewed questionnaire form in order to reach the required results. Questionnaire study samples which are Represented the employees in various administrative functions in the service of some government departments in the province of Wasit. Random samples of workers have taken whose have administrative functions, sample of size is 100 administrative officers who distributed to (10) governmental offices, and it has used various statistic methods to analyze and treat data that has got from the questionnaire by the dependence of statistic program (SPSS, vr.20). The search reached many conclusions one of them: there is the relationship between the application of total quality management and reduction of job burnout which indicate to the importance of the subjects, and it concluded several recommendations the most prominent is the services governmental offices in Wasit province have to attend to apply principles and concepts of total quality management which are successful means to limit levels of job burnout, also to achieve the quality in some services which offer from many organizations. Marwan (2016), The Role of Quality of working life in the reduction of Job Burnout phenomenon in al-Aqsa Network. This study aimed to identify the degree of the availability of quality of working life dimensions, to measure the level of job burnout as well as to detect the role of the quality of working life dimensions in the reduction of job burnout phenomenon in Al-Aqsa 
network for media and artistic production. To achieve the objectives of the study, a descriptive analytical approach was utilized and a questionnaire to collect the necessary data. The results study:

- The availability degree of quality of working life dimensions was rated to together as moderate, with a proportional weight $(61.33 \%)$.

-The level of prevalence of job burnout phenomenon among employees was (49.64\%).

- There is a weak negative $(-0.242)$ relationship between the dimensions of quality of working life and job burnout.

- Social relations and employees' participation in management had a positive significant effect on job burnout and both interpreted (7.9\%), (4.7\%) of the variation in the dependent variable, respectively.

El-Tebani, al-Agha \& Saad, (2015),'This research measures the job burnout level among academic staff at Gaza universities. It aims at studying the relationship between job burnout of academic staff at Gaza universities and organizational variables. The researchers utilized qualitative and analytical descriptive approach methodologies that match the nature of the study. The researcher used a questionnaire as a tool for collecting secondary data. The research population consists of (958) academic staff and the sample consists of (320) academic staff, who were chosen in a stratified, randomly method. There were (309) respondents representing $(97 \%)$ out of the distributed questionnaires and the researcher used the statistical program SPSS to analyze the data collected and to get the results of the research. The results show that the academic staff at the Palestinian universities in the Gaza governorates have a moderate level of job burnout in general, and there is significant evidence of the forward correlation between job burnout and the organizational variables. The research recommends that the universities should support and encourage scholarly researches on job burnout. The academic staff should participate in the decision-making process in order to tackle the staff's feelings of the lack of fairness. Additionally, positive internal social interaction and with the rest of the community members should be encouraged. The academic staff should not overwork continuously and should give themselves time to enjoy family and social life besides professional life.

Mosa \& Kalab (2012), Functional combustion and its impact on the performance of employees, the aims of this research is identifying the degree of combustion career suffered by administrators at the Emaar Association for Development and Rehabilitation and its impact on the performance of employees, as the aim of this study to uncover the relationship between the phenomenon of combustion career and some demographic variables (Age * Gender * Marital status * Education) and that by taking the sample was applied to the administrators at the Emaar Association for Development and Rehabilitation. . The sample results indicated the presence of high degrees of job combustion among all respondents in the three-dimensional components of the scale of emotional stress, and dull Humanitarian, and personal achievement. Research has shown there are differences between the sample groups on individual variables used by this research. The study put recommendations and suggestions to guide the attention of those concerned with the suffering of administrators and work to mitigate them.

\section{Amalia Venera, (2012) "The need of Total Quality Management in higher education"}

The overall objective of this thesis work is to highlight the general principles of TQM involved and to point out how this approach has been and can be used to improve the quality of an academic institution. This objective is conducted towards an evaluation and assessment of the current quality work. the way in which this university is working with quality issues now, will be compared with a TQM approach and the weaknesses and strengthens of the quality work will be recognized.

\section{Results of previous studies}

although job burnout has been widely studied in various contexts, which discussed many aspects of the subject such as the relation between levels of burnout and job satisfaction(Dioaa 2019), the impact of employee engagement and happiness on burnout (Nivethitha 2019), the impact of job satisfaction on the success of organizations (Rafsh \& Alrabeay 2018) The Role of Quality of working life in the reduction of Job Burnout ( Marwan 2016) .....etc.

All previous studies dealt with job burnout, its causes, and its effects on workers in institutions. The results of previous studies proved that there is a relationship between job fatigue for academic workers in universities and organizational changes, "job fatigue and job burnout" is one of the most important 
reasons for the resignation of many employees. The main reason behind reaching the stage of "functional combustion" is the imbalance between the inputs and the outputs, that is, the individual gives more to his work than he takes from it and neglects his personal life.

This study differs from previous studies because it dealt with the relationship between ineffective methods of applying quality management and functional combustion in Arab universities.

\section{Study Hypotheses}

The study based on the following main assumptions: -

Firstly, "There is, a significant correlation relationship between the ineffective application of quality and the presence of a number of negative aspects that cause functional combustion of faculty members in Arab universities.

Secondly, "There is, a significant correlation between the ineffective application of quality and the emotional stress of university faculty members.

Third, "There is a significant correlation relationship between the ineffective application of quality, stability and safety for faculty members in universities.

Fourth, "There is a significant correlation between the ineffective application of quality and the professional progress of university faculty members

\section{Research Limits}

The study was limited to a sample of 300 faculty members from various Arab universities, with different ages, countries, occupational degree, and number of years of experience

\section{Research Methodology}

To implement the research and test its hypotheses, the research adopts the following procedures:

\section{Method of study:}

The study adopted the descriptive survey method of random sample method that chosen within a set of determinants, and a special questionnaire has been designed for distribution to this sample. This sample includes a set of various and interrelated questions, as well as in addition to the observation and analysis of digital quantitative data obtained from during the compilation of questionnaires.

The researchers adopted the method of random sample survey that is chosen within a set of determinants that represent: gender, age, educational level, academic degree, number of years of experience among faculty members out of the total staff of Arab universities.

\section{Data collection tools and methods \\ Theoretical framework (descriptive statistical approach)}

It represented in various references and library holdings, including books, periodicals and appropriate sites on all relevant sites related to this topic on the Internet in addition to collecting data from the reality of publications and studies issued by seminars, forums and scientific conferences

\section{Secondary data - and primary data}

The researchers relied on a set of secondary data necessary to achieve goals from its various sources. The most important of these sources are Arab and foreign references, scientific journals, and periodicals, published and unpublished research for entities related to the field of research as well as university reports in this regard

\section{Initial data}

The primary data necessary to achieve the research objectives added in addition to the secondary data. Accreditation obtained in obtaining the primary data through the survey list, which directed to a random sample from all faculty members in Arab universities. A survey list designed as a research tool to measure study variables. A Five - Point Likert Scale was used so that abstract descriptive concepts can be converted into quantitative values that are easy to subject to statistical analysis and study hypotheses. The community and sample of the research consists of 300 faculty members, the questionnaire was sent to them through messages and their distribution was as follows: - 


\begin{tabular}{|l|l|l|l|}
\hline University & No. & University & No. \\
\hline Taif University & 55 & University of Sharjah & 11 \\
\hline Ain-Shams University & 32 & Arab Academy for Science & 14 \\
\hline Cairo University & 10 & Qassim University & 34 \\
\hline Suez Canal University & 15 & East Faculties 22 & 22 \\
\hline King Abdul-Aziz University & 10 & Future University & 41 \\
\hline Umm Al-Qura University & 22 & University of Dammam & 17 \\
\hline University of Dammam & 17 & & \\
\hline \multicolumn{2}{|c|}{300} & \\
\hline
\end{tabular}

\section{Data analysis methods (statistical approach)}

Statistical analysis of the data is done using the Statistical Package for the Social Science (SPSS/ PC + ), which was to achieve the goals of scientific research, and will use the following statistical methods to analyze the data of the research: -

1- Calculating the Descriptive Statistic Measures to describe the study categories based on the percentages and to arrange the study variables according to their relative importance based on the arithmetic mean and standard deviations.

2- Analysis of Variance (ANOVA) to test the differences between the averages of the study categories about the variables.

3- Simple Regression analysis to test the effect of each independent variable individually on the dependent variable.

\section{Practical study: -}

\begin{tabular}{|l|l|l|l|}
\hline Lecturer & $\begin{array}{l}\text { Assistant } \\
\text { Professor }\end{array}$ & $\begin{array}{l}\text { Associate } \\
\text { Professor }\end{array}$ & Professor \\
\hline 36 & 186 & 36 & 42 \\
\hline $12 \%$ & $\% 62$ & $\% 12$ & $\% 14$ \\
\hline
\end{tabular}

\begin{tabular}{|c|c|}
\hline Female & Male \\
\hline 156 & 144 \\
\hline $52 \%$ & $48 \%$ \\
\hline
\end{tabular}

\begin{tabular}{|l|l|l|l|l|}
\hline & Lecturer & $\begin{array}{l}\text { Assistant } \\
\text { Professor }\end{array}$ & $\begin{array}{l}\text { Associate } \\
\text { Professor }\end{array}$ & Professor \\
\hline \multirow{2}{*}{ Female } & 22 & 98 & 19 & 17 \\
\cline { 2 - 5 } & $14 \%$ & $63 \%$ & $12 \%$ & $11 \%$ \\
\hline \multirow{2}{*}{ Male } & 14 & 88 & 17 & 25 \\
\cline { 2 - 5 } & $10 \%$ & $61 \%$ & $12 \%$ & $17 \%$ \\
\hline
\end{tabular}

\begin{tabular}{|l|l|l|l|}
\hline $\begin{array}{l}\text { Less than } 5 \\
\text { years }\end{array}$ & $\begin{array}{l}5-10 \\
\text { years }\end{array}$ & $10-15$ years & $\begin{array}{l}\text { More than } 15 \\
\text { years }\end{array}$ \\
\hline 36 & 62 & 176 & 26 \\
\hline $12 \%$ & $\% 21$ & $\% 59$ & $\% 8$ \\
\hline
\end{tabular}

\section{Results of data analysis}

\begin{tabular}{|l|l|}
\hline Academic & $\begin{array}{l}\text { Academic } \\
\text { Administrative }\end{array}$ \\
\hline 192 & 108 \\
\hline $64 \%$ & $\% 36$ \\
\hline
\end{tabular}

The results related to the extent of the existence of an actual relationship between the ineffective application of quality and the presence of a number of negative phenomena that cause job combustion for faculty members. 
The following table (1) shows the accounting averages, standard deviations, and the order of relative importance of the estimates of the members of the study sample about the extent of the actual relationship.

Table (1)

\begin{tabular}{|l|l|l|l|l|}
\hline $\begin{array}{l}\text { First } \\
\text { Phrases }\end{array}$ & $\begin{array}{l}\text { Arithmetic } \\
\text { mean }\end{array}$ & $\begin{array}{l}\text { Standard } \\
\text { deviation }\end{array}$ & Arrangement & Usage \\
\hline 1 & 4.24 & 0.63 & First & High \\
\hline 2 & 3.83 & 0.86 & Forth & High \\
\hline 3 & 3.99 & 0.78 & Second & High \\
\hline 4 & 3.97 & 0.79 & Third & High \\
\hline 5 & 3.93 & 0.88 & Fifth & High \\
\hline Total & 3.96 & 0.76 & & High \\
\hline
\end{tabular}

To answer the first question (the extent to which the members of the sample feel that there is an effective relationship between the ineffective application of quality and the reasons leading to job burnout)

Table (2) shows the results of all the arithmetic averages for the four dimensions indicate greater than the test criterion of (3) out of (5) degrees and these results indicate that the level of evaluation of the members of the study sample for the importance of the mentioned dimensions was positive.

This means that the members of the sample confirm the existence of a relationship Effective between the ineffective application of quality and causes leading to functional combustion in a high degree from their point of view.

Results related to the extent of the transformation of these negative phenomena and the extent of their transformation into what is called emotional stress

Table (2)

\begin{tabular}{|l|l|l|l|}
\hline Axis Phrases & $\begin{array}{l}\text { Arithmetic } \\
\text { mean }\end{array}$ & $\begin{array}{l}\text { Standard } \\
\text { deviation }\end{array}$ & Evaluation \\
\hline 1 & 3.27 & 1.24 & Average \\
\hline 2 & 3.07 & 1.30 & Average \\
\hline 3 & 2.94 & 1.29 & Average \\
\hline 4 & 2.76 & 1.34 & Average \\
\hline 5 & 3.18 & 1.25 & Average \\
\hline 6 & 3.11 & 1.38 & Average \\
\hline $\begin{array}{l}\text { General mean } \\
\text { and standard } \\
\text { deviation }\end{array}$ & 3.05 & 1.47 & \\
\hline
\end{tabular}

To answer the second question (the extent to which these negative manifestations turn into what is called emotional stress)

Table (3) shows the results indicate that the general arithmetic average reached (3.05) with a standard deviation (1.47), which indicates that the evaluation of the sample members that there are some aspects of the shift to emotional stress in addition to the sample's lack of feeling of these aspects with an average degree inclined to the high degree.

As for energy depletion and emotional depletion, it has shown that it ranked first with an arithmetic average (3.27) and a standard deviation (1.24). In the question about (the state of boredom, boredom, and general frustration) it came in the last rank from the point of view of the study sample with an arithmetic average of (2.76) and a standard deviation (1.34)

In spite of this, all the results of all the averages calculated for the paragraphs that the level of evaluation of the members of the study sample for the feeling of stress (average) degree from their point of view

The results related to the extent of the matter reaching the teaching staff member feeling a sense of insecurity and job stability in the work and whether it reflected in his academic performance Table (3) 


\begin{tabular}{|l|l|l|l|}
\hline Axis Phrases & $\begin{array}{l}\text { Arithmetic } \\
\text { mean }\end{array}$ & $\begin{array}{l}\text { Standard } \\
\text { deviation }\end{array}$ & Evaluation \\
\hline 1 & 3.89 & 1.07 & High \\
\hline 2 & 3.68 & 1.05 & High \\
\hline 3 & 3.91 & 0.87 & High \\
\hline 4 & 3.84 & 1.08 & High \\
\hline $\begin{array}{l}\text { General mean } \\
\text { and standard } \\
\text { deviation }\end{array}$ & 3.95 & 0.78 & High \\
\hline
\end{tabular}

Table (3) shows the results showed that (the university administration uses a clear mechanism concerned with the opinions and observations of workers)

came first on the scale of priorities for the evaluation of the study sample individuals with an arithmetic average of (3.91), and a standard deviation (0.87) while paragraph (2) related to the search for other opportunities because of my continuation In my current job, I am not guaranteed in the fourth rank with an arithmetic average (3.68), a standard deviation (1.05), and the results of all the arithmetic mean for the paragraphs as being greater than the selection criterion of (3) out of (5) degrees.

This indicates that the faculty member feels a kind of insecurity and stability Career at work and whether it was reflected my academic performance was (positive) and very high.

4. Results related to the results of the study Results related to the extent of the professional progress of faculty members in universities

Table (4)

\begin{tabular}{|l|l|l|l|l|l|l|l|l|}
\hline $\begin{array}{l}\text { Axis } \\
\text { Phrases }\end{array}$ & S. Agree & Agree & neutral & Disagree & $\begin{array}{l}\text { S. } \\
\text { Dis. }\end{array}$ & Std. Dev. & Mean & Sig. \\
\hline 1 & $18 \%$ & $33 \%$ & $24 \%$ & $21 \%$ & $4 \%$ & 1.171 & 3.227 & .000 \\
\hline 2 & $26 \%$ & $58 \%$ & $14 \%$ & $2 \%$ & 0 & 0.667 & 4.111 & .000 \\
\hline 3 & $30 \%$ & $46 \%$ & $20 \%$ & $4 \%$ & 0 & 0.815 & 3.974 & .000 \\
\hline 4 & $14 \%$ & $56 \%$ & $18 \%$ & $8 \%$ & $4 \%$ & 0.849 & 4.026 & .000 \\
\hline 5 & $45 \%$ & $38 \%$ & $12 \%$ & $3 \%$ & $2 \%$ & 0.825 & 3.412 & .000 \\
\hline 6 & $52 \%$ & $28 \%$ & $12 \%$ & $8 \%$ & 0 & 1.096 & 2.780 & .000 \\
\hline 7 & $44 \%$ & $38 \%$ & $10 \%$ & $6 \%$ & $2 \%$ & 1.014 & 3.326 & .000 \\
\hline
\end{tabular}

Table (4) shows the results of all the calculated arithmetic mean for the items indicated the degree of influence of the professional progress of faculty members in universities was (average) degree from their point of view

We note that the mean and the standard deviation of all the answers are close and within the normal distribution of the sample, and this indicates that there are no significant differences in the answers of the study sample.

In addition, if we compare these values with the general average of all the answers we find also close, as the value of sig for all the results of the study 0.000 , this means that the results of the statistical analysis are significant for all the questions that were directed to the study sample.

Through question (1) we note that $42 \%$ of the sample size agrees that I participate in conducting research and research projects from the allocations of scientific research, and that $14 \%$ of the sample size does not agree to this and this means accepting the second hypothesis (2A) which states that "there is a relationship Significant correlation between ineffective application of quality and emotional stress to university faculty members. As for the endeavor to participate in conferences, $64 \%$ of the sample agreed to this, but with regard to participation in activities outside the university to serve the community, $58 \%$ of the sample supported that, and here comes the confirmation of accepting the first hypothesis, which was previously proven (1 A).

As for the sympathy with colleagues in developing curricula, $88 \%$ of the sample confirmed that they are already doing so. 
With regard to the occurrence of clear deficiencies in the professional progress of faculty members, the approval rate ranged between $50 \%-80 \%$ of the study sample and thus accepting the fourth hypothesis (4A) which states, "There is a significant correlation relationship between the ineffective application of quality and professional progress for faculty members in universities.

"With regard to seeking to participate in conferences and seminars and conducting research projects, $90 \%$ of the study eye supported their endeavor to do so, and this was evident by the shrinking role of universities in providing material and moral support and time for faculty members to play this role.

We conclude from this that: -

The ineffective application of quality within Arab Universities has strongly reflected on all faculty members and has led to the emergence of forms of combustion for all faculty members as well as reducing the main role of the faculty member.

In addition to the emergence of some psychological problems and pictures of images of psychological and emotional stress and general frustration for the faculty members, this has been reflected in the injury with many cases of general stress and raising the level of blood pressure.

The role of universities in assigning faculty members to participate in cultural and scientific conferences as well as reducing the times allocated for conducting research has decreased significantly, and thus the faculty has increased reliance on seeking to participate and conduct research individually.

Table (5)

\begin{tabular}{|c|c|c|c|c|}
\hline Axis Phrases & $\begin{array}{l}\text { Arithmetic } \\
\text { mean }\end{array}$ & $\begin{array}{l}\text { Standard } \\
\text { deviation }\end{array}$ & Calculated (t) & $\begin{array}{l}\text { Statistical } \\
\text { significance }\end{array}$ \\
\hline \multirow[t]{4}{*}{1} & 4.50 & 0.01 & \multirow[t]{4}{*}{5.707} & \multirow[t]{4}{*}{0.001} \\
\hline & 4.18 & 0.83 & & \\
\hline & 4.34 & 0.34 & & \\
\hline & 2.65 & 0.07 & & \\
\hline \multirow[t]{4}{*}{2} & 4.00 & 0.01 & \multirow[t]{4}{*}{2.434} & \multirow[t]{4}{*}{0.071} \\
\hline & 3.84 & 0.99 & & \\
\hline & 3.87 & 0.74 & & \\
\hline & 2.25 & 0.01 & & \\
\hline \multirow[t]{4}{*}{3} & 4.70 & 0.01 & \multirow[t]{4}{*}{6.401} & \multirow[t]{4}{*}{0.001} \\
\hline & 4.16 & 0.85 & & \\
\hline & 3.90 & 0.64 & & \\
\hline & 2.10 & 0.14 & & \\
\hline \multirow[t]{4}{*}{4} & 4.58 & 0.29 & \multirow[t]{4}{*}{3.037} & \multirow[t]{4}{*}{0.034} \\
\hline & 4.09 & 0.94 & & \\
\hline & 3.89 & 0.61 & & \\
\hline & 2.69 & 0.97 & & \\
\hline
\end{tabular}

Table (5) shows there were no statistically significant differences at the level of significance $(\alpha=$ 0.05 ) between the averages of the responses of the study sample individuals about the dimension (negative aspects that cause functional combustion),

Also that the value of the statistical significance of $(0.071)$ is greater than the level of significance ( $a$ $=0.05)$ the reasoning of individual acceptance is that there is a significant correlation relationship between the ineffective application of quality and the presence of a number of negative aspects that cause functional burnout for faculty members.

Indicators of Survey $(\mathrm{T})$ of the Arab Universities State of Africa, including the scientific degree, according to scientific studies.

Table (6)

\begin{tabular}{|l|l|l|l|l|l|}
\hline Axis Phrases & $\begin{array}{l}\text { Arithmetic } \\
\text { mean }\end{array}$ & $\begin{array}{l}\text { Standard } \\
\text { deviation }\end{array}$ & $\begin{array}{l}\text { Years of } \\
\text { Experience }\end{array}$ & Calculated (t) & $\begin{array}{l}\text { Statistical } \\
\text { significance }\end{array}$ \\
\hline \multirow{2}{*}{1} & 4.31 & 0.41 & Less than5 & \multirow{2}{*}{1.043} & \multirow{2}{*}{0.357} \\
\cline { 2 - 4 } & 4.12 & 0.81 & $10-5$ & & \\
\cline { 2 - 4 } & 4.36 & 0.78 & $15-10$ & & \\
\hline
\end{tabular}




\begin{tabular}{|c|c|c|c|c|c|}
\hline & 4.33 & 0.42 & More 15 & & \\
\hline \multirow[t]{4}{*}{2} & 3.88 & 0.72 & Less than5 & \multirow[t]{4}{*}{0.154} & \multirow{4}{*}{0.858} \\
\hline & 3.78 & 0.98 & $10-5$ & & \\
\hline & 3.75 & 1.14 & $15-10$ & & \\
\hline & & & More 15 & & \\
\hline \multirow[t]{4}{*}{3} & 3.99 & 0.71 & Less than5 & \multirow[t]{4}{*}{0.137} & \multirow[t]{4}{*}{0.872} \\
\hline & 4.03 & 0.82 & $10-5$ & & \\
\hline & 3.86 & 1.14 & $15-10$ & & \\
\hline & 3.99 & 0.72 & More 15 & & \\
\hline \multirow[t]{4}{*}{4} & 4.03 & 0.61 & Less than 5 & \multirow[t]{4}{*}{0.342} & \multirow[t]{4}{*}{0.711} \\
\hline & 3.92 & 0.89 & $10-5$ & & \\
\hline & 3.81 & 1.18 & $15-10$ & & \\
\hline & 3.83 & 1.14 & More 15 & & \\
\hline
\end{tabular}

Table (6) shows the absence of statistically significant differences at the level of significance ( $\alpha=$ 0.05 ) between the averages of the responses of the members of the study sample and the higher acceptance of individualism. Teaching at universities and its reflection on your participation in local and international conferences and seminars.

\section{Conclusions}

\section{The results of the study showed the following: -}

There are very negative aspects of the ineffective application of quality at the university, which is reflected by everyone who works in the university field at the level of Arab universities, which led to reducing the important scientific and pivotal role of the faculty member to become a primary preparatory of quality reports with exhausted periodicity.

There is a removal from the types of boredom and general frustration, as well as unjustified fatigue resulting from the constant pressure of quality requests in a disturbing manner, which is called emotional stress.

The faculty member faces several requirements between the basic tasks of the teaching function, the quality requirements, and professional development on the one hand, as well as the general depletion of mental, muscular, and psychological capabilities.

$88 \%$ of the study sample confirmed that, despite this, they are cooperating with colleagues in order to develop academic curricula and develop university work, despite bearing the intense pressure burdened with quality requirements.

Many faculty members suffer from the lack of clarity in the university's mechanism to take care of the opinions and observations of employees, as well as $76 \%$ suffer from severe pressure because of direct interaction.

\section{Recommendations}

For university, officials have to pay attention to studying the phenomenon of job combustion and to work out their causes and devise appropriate solutions to mitigate its spread.

The study proposes identifying practical paths for the faculty member so that we have a teaching path, a scientific research path, development, quality path, a community service path.

Suggested that these paths be optional for the faculty member, to choose the appropriate path for his talents and that for limited periods, two or four years, so that the faculty member can develop his skills in all academic tracks in general.

Allocating financial rewards to the faculty members if he is assigned tasks related to quality management.

\section{References}

Akkady, H. (2017). Organizational climate and its relationship to job combustion, MA.

Al-Bouhi, R., Almasry I., \& Others (2014). Total Quality in Education, Dar Al-Elm and Al-Iman Publishing, 2014, p. 268.

Benchmarking: An International Journal, Issue(s) available: 127 - From Volume: 6 Issue: 1, to Volume: 26 Issue:8. 
El-Tebani, N., Algha, M., \& Saadallah, R. (2015). The Relationship of the Organizational Factors with Job Burnout among the Academic Staff at the Palestinian Universities. An-Najah University Journal for Research (Humanities) Volume 29 (4, 2015)

Marwan, A. (2016). 'The Role of Quality of working life in the reduction of Job Burnout phenomenon in Al-Aqsa Network for Media \& Artistic Production'

Mosa, A. \& Kalab, Y. (2012). Functional combustion and its impact on the performance of employeesm, Community Development Institute, slamic University of Gaza. 2nd World Conference on Educational Technology Researches WCETR, 2012. http://www.wcetr.org

Naser, A. (2017). The importance of the application of a total quality management system to limit the phenomenon of Job Burnout, Journal of Economic and Administrative Sciences - issued by the College of Administration and Economics / University of Wasit - Issue (27), September 2017.

Nashwan, J. (2004). Developing Competencies for Academic Supervisors in University Education in the Light of the Concept of Total Quality Management, Quality Conference in Palestinian University Education, Al-Quds Open University, July 2004, p. 8.

Osman, D. \& Abdreheem, S. (2019). Burnout and Job Satisfaction among Healthcare Providers in Aswan University, Journal of High Institute of Public Health 2019;49(1):64-72.

Rafsh, S., \& Alrabeay, M. (2018,). The impact of job satisfaction on the success of organizations, International Conference.

Saleh, R. (2017). The effect of empowering workers on job combustion: a field study at the General Company for Iraqi Ports in Basra, Journal of Management and Economics - University of Karbala, ISSN: 22215794 Year: 2017 Volume: 6 Issue: 23 Pages: 58-76, Publisher: Karbala University.

Shaalan, F. (2016) The Arab Journal of Security Studies and Training" Volume 32, Issue 65, Riyadh.

Stela, S. (2017). Narratives of burnout and recovery from an agency perspective: A two-year longitudinal study, journal homepage: The Arab Journal for Security Studies and Training Volume 32 Issue (65) 354 Riyadh (2016) (1437).

Trivedi, T. \& Shukla, A. (2008). Burnout in Indian Teachers. Asia, Pacific Education Review, Humanities, Social Sciences \& Law, 9, (3), 320-334

http:/ / dr-alameri.com/wp-content/uploads/2018/04/\%D8\%A7\%D9\%84\%D9\%85\%D9\%86\%D8\%A7\%D8\%AE\%D8\%A7\%D9\%84\%D8\%AA\%D9\%86\%D8\%B8\%D9\%8A\%D9\%85\%D9\%8A-

\%D9\%88\%D8\%B9\%D9\%84\%D8\%A7\%D9\%82\%D8\%AA\%D9\%87-

\%D8\%A8\%D8\%A7\%D9\%84\%D8\%A7\%D8\%AD\%D8\%AA\%D8\%B1\%D8\%A7\%D9\%82-

\%D8\%A7\%D9\%84\%D9\%88\%D8\%B8\%D9\%8A\%D9\%81\%D9\%8A-pdf.pdf

https://journals.nauss.edu.sa > index.php > AJSS

https://books.google.com.sa/books?id=WLBGDwAAQBAJ\&pg=PA268\&lpg=PA268\&dq=http://valrocha.+Com/w eb/quality/14.htm.\&source=bl\&ots=YK5yMEZOLi\&sig=ACfU3U2AE5jstWq3cSd3HlmXhxtmCuDuNg\&hl=e n\&sa=X\&ved=2ahUKEwi3kuHVsoPoAhULlxQKHewvC_QQ6AEwAHoECAoQAQ\#v=onepage\&q=http \%3A \%2F\%2Fvalrocha. \%20Com\%2Fweb\%2Fquality\%2F14.htm.\&f=falsejhiphalexu.journals.ekb.eg

https:// onlinelibrary.wiley.com/doi/10.1002/jgc4.1133

https://www.emeraldinsight.com/1463-5771.htm

http://164.100.133.129:81/econtent/Uploads/Advanced_Human_Resource_Management.pdf

www.sciencedirect.com.

https://www.iasj.net

www.elsevier.com/locate/burn

https://journals.najah.edu/media/journals/full_texts/4_tPzbDNr.pdf

http:/ / cdi.iugaza.edu.ps/Files/6642f659-676d-4a73-8757-c95dbb156faa.pdf

http:/ / hdl.handle.net/20.500.12358/20290

https:/ / www.iasj.net/iasj?func=fulltext\&aId=138786.

https://doi.org/10.1108/S0732.

file:/ / C:/Users/drnou/Downloads/refguide.pdf. 